\title{
Knowledge, Attitudes, and Practice Related to Cervical Cancer Screening among Kuwaiti Women
}

\author{
Mona Al Sairafi ${ }^{a}$ Farida A. Mohamed ${ }^{b}$ \\ ${ }^{a}$ Mishref Clinic, Hawalli Health District, ${ }^{b}$ Rumethia Primary Health Care Clinic, Hawalli Health District, Kuwait
}

\section{Key Words}

Cervical cancer Papanicolaou smear screening •

Knowledge $\cdot$ Kuwait

\begin{abstract}
Objectives: To assess the knowledge, attitude, and practice regarding cervical cancer screening among Kuwaiti women. Subjects and Methods: A total of 300 married Kuwaiti women were randomly selected from those who visited the clinics irrespective of reason(s) for the visit. A structured questionnaire covering sociodemographic characteristics, knowledge, attitude, and practice related to cervical cancer screening was administered. Results: Of the 300 women, complete information was collected from 281 (93.7\%), the knowledge about the test was adequate in 147 (52.3\%) women, while $86(30.6 \%)$ had adequate attitude towards the test and only $67(23.8 \%)$ had an adequate practice. The main reason given for not having had a Papanicolaou smear was that it was not suggested by the doctor. Among all the respondents 220 (78.7\%) would prefer a female doctor to conduct the test. The level of education was the only significant factor independently associated with inadequate knowledge and attitude towards Papanicolaou smear test $(p=0.006$ and $p=0.001$, respectively) when adjusted for the effect of other factors in multivariate logistic regression analysis. However, age $(p<0.001)$, level of education $(p=0.028)$, and number of
\end{abstract}

years since last visit with a gynaecologist $(p=0.005)$ were significant factors independently associated with inadequate practice of the test. Conclusion: Our findings showed that a well-designed health education programme on cervical cancer and benefits of screening would increase the awareness among Kuwaiti women.

Copyright $\odot 2008$ S. Karger AG, Basel

\section{Introduction}

Cancer of the cervix uteri is the second most common cancer among women worldwide, with an estimated 468,000 new cases and 233,000 deaths in the year 2000 [1]. Almost $80 \%$ of the cases occurred in developing countries. It is one of the leading causes of gynaecological cancer-related mortality and morbidity in developing countries [2]. Fortunately, cervical cancer is a preventable and treatable disease; early detection has reduced its mortality and morbidity worldwide [3]. The Papanicolaou (Pap) smear is an efficient, affordable, and effective method of detecting cytological changes in the uterine cervix. It plays an important role in screening programmes in reducing both the incidence and mortality of invasive cancer [4]. The goal of routine screening is to detect early cytological changes such as dysplasia and to treat the patient before cervical cancer develops. In countries where

\section{KARGER}

Fax +41613061234

E-Mail karger@karger.ch

www.karger.com
(C) 2008 S. Karger AG, Basel

1011-7571/09/0181-0035\$26.00/0

Accessible online at:

www.karger.com/mpp
Mona Al Sairafi

Mishref Clinic, Hawalli Health District

PO Box 526, Mishref 40156 (Kuwait)

Tel. +965972 0083, Fax +965 5389526

E-Maildr_manaalsaiyrafi@yahoo.com 
Pap smear testing covers a wide population, both the incidence and prevalence of cervical cancer has been dramatically reduced [5-7]. It has been observed that the decrease in incidence rates is more evident in countries with organized screening programmes [5].

The risk for developing cervical cancer is associated with early age of first intercourse, multiple sexual partners, smoking and infection with human Papillomavirus [1]. The overwhelming majority of women with a diagnosis of cervical cancer have either not had Pap tests or have not been followed up after detection of an abnormal smear. Not undergoing regular Pap tests is the single greatest risk factor for a poor outcome in women who develop cervical cancer [8]. American Cancer Society and American College of Obstetricians and Gynecologists recommend annual Pap smear screening for women who are sexually active, less frequent screening in women who have had 3 consecutive normal smears $[9,10]$. The WHO recommendations on target ages and frequency of cervical cancer screening state that screening should start on women aged 30 years or more, a 3-year interval can be considered in the age group 25-49 years, and screening is not necessary for women over 65 years [11].

A relatively low prevalence of abnormal smears and cervical cancer has been reported in the Muslim as compared to the Western population [12-15]. Probable explanations include sexual behaviour under Islamic rules [12], lack of awareness of cervical cancer risk factors among women, and low awareness that routine gynaecological examinations and Pap smears are essential [13]. Gynaecological malignancies amounted to $13 \%$ of all female cancers reported among Kuwaiti women in 2002 and the incidence of cervical cancer was 3.5 per 100,000 population [16]. According to the WHO Statistical Information System, the estimated mortality rate for Kuwaiti women from cervical cancer was 0.2 per 100,000 population in 2002 [17]. Squamous cell abnormalities and invasive squamous cell carcinoma are less frequently encountered in Kuwaiti women as compared to the Western world [18]. Unfortunately, there is no population-based cervical screening programme in Kuwait. The purpose of this study was to assess the knowledge, attitude and practice related to cervical cancer screening among Kuwaiti women.

\section{Subjects and Methods}

For administrative purposes, Kuwait is divided into five health regions: Capital, Hawalli, Farwania, Jahra and Ahmadi. The primary healthcare services in each health region comprise a num- ber of polyclinics, which provide primary, maternal, child, and dental healthcare services. We decided to study the knowledge, attitudes, and practice related to cervical cancer screening among Kuwaiti women in the urban, densely populated Hawalli health region. There are 11 polyclinics in the Hawalli region, 4 of them are specialized maternity clinics. Among the 4 specialized maternity clinics, 2 polyclinics (polyclinics in Salwa and Rumethia) were randomly selected and hence our sample was not population-based. A total of 300 ever-married Kuwaiti women were randomly selected from women who visited the clinics during the period of April to September 2006 irrespective of the reasons for the visit; 19 women refused participation for personal reasons, and we were able to collect information from a total of 281 women. Written informed consent was obtained from all the women who participated in the study.

A structured questionnaire with questions on sociodemographic characteristics (age, educational and employment status, personal monthly income, marital status, age at first marriage, parity, smoking status, contraceptive use and perceived health status), knowledge about cervical cancer and Pap smear testing, source of information about the Pap test, and previous screening history was administered. Questions on barriers that prevented them from taking the test in the past year, gender preference for the physician to conduct the cervical screening test, and their intention to participate in a national cervical cancer screening programme if such a programme was initiated by the Ministry of Health were also included. Questionnaires were administered during face-to-face interviews conducted in Arabic by 2 physicians (M.A.S. and F.A.M.). The reliability of the questionnaire was tested in a sample of 50 subjects demonstrating a high level of reliability $(\kappa=0.87)$.

We adopted the following definitions in the analysis [19]. Adequate knowledge: women who had heard of the test and knew that it was for detecting cancer in general or cervical cancer specifically. Inadequate knowledge: women who had never heard of the test, or who had heard of it but were not aware that it were aimed to detect cancer or cervical cancer. Adequate attitude: women who considered it necessary to undergo the test periodically, i.e., once every 3 years, which is related to their knowledge on screening policy. Inadequate attitude: women who had never heard of the test, or who had heard of it but considered it not necessary to undergo the test, or who had no opinion on the matter. Adequate practice: women who underwent the test in the 3 years prior to data collection. Inadequate practice: women who underwent the test more than 3 years prior to data collection or who never had the test.

All statistical analyses were performed using the Statistical Package for Social Sciences, ver. 14.0 (SPSS Inc., Chicago, Ill., USA), and statistically significant test was set at $\mathrm{p}<0.05$. The $\chi^{2}$ test was used to assess the association between two qualitative variables. The multiple logistic regression analysis was used to estimate the risk of different factors for inadequate knowledge, attitudes and practice of Pap smear test ( 0 for adequate and 1 for inadequate) after controlling confounding between them. The independent variables: age, education level, working status, income, marital status, number of marriages, age at first marriage, number of pregnancies, use of contraceptives, and number of years since last visited gynaecologists were included in the model to control for confounding. The adjusted odds ratios and their $95 \%$ CI for associated factors are reported. 


\section{Results}

The sociodemographic characteristics of the 281 studied women are presented in table 1 . The mean age was $36.5 \pm 9.7$ years (range 19-66 years), 179 (63.9\%) of them had secondary school education level or above, 179 (63.7\%) were working outside home, and 145 (51.8\%) had a monthly income more than $1,000 \mathrm{KD}(1 \mathrm{KD} \approx 3.3$ USD). The majority $(251,89.3 \%)$ of the women were married and are living with their partners, the remaining 30 $(10.7 \%)$ were divorced or widowed, 258 (92.1\%) were married once, the mean age at first marriage was $20.8 \pm 3.7$ years and the number of pregnancies ranged from 0 to 13 with 4 as median. A total of 270 (74.3\%) reported that they used contraceptives, mainly hormonal contraceptives 135 (48.1\%), and more than half of the women had at least one visit to a gynaecologist during the last year.

Regarding the knowledge of Pap smear test, 216 (76.9\%) of the women reported having heard of the test; the source of knowledge was mostly from a gynaecologist $(\mathrm{n}=118$, $42 \%)$, followed by friends/relatives $(\mathrm{n}=60,21.4 \%)$ and media ( $n=41,14.6 \%$ ) (table 2). The opinion of the women about the purpose the test was 'to discover cervical cancer' $(\mathrm{n}=116,41.3 \%)$, followed by 'to treat vaginal inflammations' ( $\mathrm{n}=126,44.8 \%)$. Among those who had heard of the test, 168 (84.2\%) believed that every woman has to be taken for Pap smear test and only 119 (42.3\%) knew that the test must be taken regularly. Regarding the practice of Pap smear test among studied women, only 99 (35.2\%) ever had the test and only 26 (26.3\%) of them had undergone the test more than once. The majority of women $(n=220,78.7 \%)$ preferred a female doctor to take their Pap smear test and only 46 (15.4\%) did not express a preference. The main reason that prevented them from going for the test was 'doctor never suggested' $(\mathrm{n}=88)$, followed by 'the test is painful' ( $n=32)$, afraid of infection $(n=27)$, afraid of detecting cancer $(\mathrm{n}=8)$, no symptoms $(\mathrm{n}=19)$ and embarrassment $(n=23)$. The majority $(n=236)$ of studied women liked to know more about Pap smear test and were willing to participate in a national cervical cancer screening programme if the Ministry of Health initiates such a programme.

The adequacy of knowledge, attitude and practice regarding the Pap smear test among the women are given in table 3 . The knowledge about the test was adequate in $147(52.3 \%)$ women, while $86(30.6 \%)$ women had adequate attitude towards the test. Only $67(23.8 \%)$ had an adequate practice.

The associations of adequacy of knowledge, attitude and practice of the Pap smear test with sociodemograph-
Table 1. Characteristics of the women

\begin{tabular}{|c|c|c|}
\hline \multirow[t]{2}{*}{ Characteristic } & \multicolumn{2}{|c|}{ Women $(\mathrm{n}=281)$} \\
\hline & $\mathrm{n}$ & $\%$ \\
\hline \multicolumn{3}{|l|}{ Age, years } \\
\hline $20-29$ & 73 & 26.0 \\
\hline $30-39$ & 102 & 36.3 \\
\hline $40-49$ & 76 & 27.0 \\
\hline$\geq 50$ & 30 & 10.7 \\
\hline Mean (SD) & \multicolumn{2}{|c|}{$36.5(9.7)$} \\
\hline \multicolumn{3}{|l|}{ Education level } \\
\hline Secondary or below & 101 & 36.1 \\
\hline Diploma & 109 & 38.9 \\
\hline University and above & 70 & 25.0 \\
\hline \multicolumn{3}{|l|}{ Working status } \\
\hline Working & 179 & 63.7 \\
\hline Retired & 40 & 14.2 \\
\hline Housewife & 62 & 22.1 \\
\hline \multicolumn{3}{|l|}{ Monthly income, KD } \\
\hline$<500$ & 35 & 12.5 \\
\hline $500-999$ & 100 & 35.7 \\
\hline$\geq 1,000$ & 145 & 51.8 \\
\hline \multicolumn{3}{|l|}{ Marital status } \\
\hline Married & 251 & 89.3 \\
\hline Divorced & 21 & 7.5 \\
\hline Widowed & 9 & 3.2 \\
\hline \multicolumn{3}{|l|}{ Number of marriages } \\
\hline 1 & 258 & 92.1 \\
\hline$\geq 2$ & 22 & 7.8 \\
\hline \multicolumn{3}{|l|}{ Age at first marriage, years } \\
\hline$<20$ & 108 & 41.2 \\
\hline $20-25$ & 124 & 47.3 \\
\hline$>25$ & 30 & 11.5 \\
\hline Mean (SD) & \multicolumn{2}{|c|}{$20.8(3.7)$} \\
\hline \multicolumn{3}{|l|}{ Number of pregnancies } \\
\hline None & 21 & 8.5 \\
\hline $1-5$ & 152 & 61.8 \\
\hline$\geq 6$ & 73 & 29.7 \\
\hline Median (range) & \multicolumn{2}{|c|}{$4(0-13)$} \\
\hline \multicolumn{3}{|l|}{ Contraception $^{1}$} \\
\hline Do not use & 75 & 26.7 \\
\hline Hormonal contraceptives & 135 & 48.1 \\
\hline Coitus interruptus/condom & 83 & 29.6 \\
\hline IUD/ligation & 52 & 18.5 \\
\hline \multicolumn{3}{|c|}{ Years since last visited gynaecologist } \\
\hline$<1$ & 142 & 54.4 \\
\hline $1-<2$ & 47 & 18.0 \\
\hline$\geq 2$ & 72 & 27.6 \\
\hline Median (range) & \multicolumn{2}{|c|}{$0.58(0.08-10)$} \\
\hline
\end{tabular}

Numbers may not add up to the total due to missings.

${ }^{1}$ More than one answer is possible and hence the sum may be greater than $100 \%$. 
Table 2. Knowledge, attitudes and practice regarding Pap smear screening among studied women

\begin{tabular}{|c|c|c|}
\hline \multirow[t]{2}{*}{ Characteristic } & \multicolumn{2}{|c|}{ Women } \\
\hline & $\mathrm{n}$ & $\%$ \\
\hline \multicolumn{3}{|l|}{ Heard about the Pap test } \\
\hline Yes & 216 & 76.9 \\
\hline No & 65 & 23.1 \\
\hline \multicolumn{3}{|l|}{ Source of knowledge ${ }^{1}$} \\
\hline Gynecologist/family doctor & 118 & 42.0 \\
\hline Friends/relatives & 60 & 21.4 \\
\hline Media & 41 & 14.6 \\
\hline Health publications & 24 & 8.5 \\
\hline Lectures/conferences & 22 & 7.8 \\
\hline \multicolumn{3}{|l|}{ Opinion about the purpose of test ${ }^{1}$} \\
\hline To discover any cervical cancer changes & 116 & 41.3 \\
\hline To discover any cancer in the body & 15 & 5.3 \\
\hline To treat vaginal inflammations & 126 & 44.8 \\
\hline Do not know & 82 & 29.2 \\
\hline \multicolumn{3}{|l|}{ Every woman must take Pap smear test } \\
\hline Yes & 168 & 84.2 \\
\hline No & 48 & 15.7 \\
\hline Do not know & 65 & 23.1 \\
\hline \multicolumn{3}{|l|}{ Pap smear test must be taken regularly } \\
\hline Yes & 119 & 42.3 \\
\hline No & 96 & 34.2 \\
\hline Do not know & 66 & 23.5 \\
\hline \multicolumn{3}{|l|}{ Ever had a Pap smear test } \\
\hline Yes & 99 & 35.2 \\
\hline No & 182 & 64.8 \\
\hline \multicolumn{3}{|l|}{ Frequency of taking the test } \\
\hline 1 & 73 & 73.7 \\
\hline 2 & 19 & 19.2 \\
\hline$\geq 3$ & 7 & 7.1 \\
\hline Median (range) & \multicolumn{2}{|c|}{$1(1-5)$} \\
\hline \multicolumn{3}{|l|}{ Reasons for not taking the test ${ }^{1}$} \\
\hline Doctor never suggested & 88 & 48.4 \\
\hline Painful & 32 & 17.6 \\
\hline Afraid of infection & 27 & 14.8 \\
\hline Embarrassment & 23 & 12.6 \\
\hline No symptoms & 19 & 10.4 \\
\hline Afraid of discovery of cancer & 18 & 9.9 \\
\hline Worthless & 15 & 8.2 \\
\hline Abortion & 5 & 2.7 \\
\hline No reason & 33 & 18.1 \\
\hline \multicolumn{3}{|c|}{$\begin{array}{l}\text { Willing to participate in a national cervical cancer } \\
\text { screening programme }\end{array}$} \\
\hline Yes & 220 & 78.6 \\
\hline No & 61 & 21.4 \\
\hline \multicolumn{3}{|l|}{ Like to know more about Pap smear test } \\
\hline Yes & 236 & 84.3 \\
\hline No & 44 & 15.7 \\
\hline \multicolumn{3}{|l|}{ Like to take Pap smear by } \\
\hline Female doctor & 220 & 78.7 \\
\hline Male doctor & 16 & 5.8 \\
\hline No difference & 46 & 16.5 \\
\hline
\end{tabular}

\footnotetext{
${ }^{1}$ More than one answer is possible and hence the sum may be greater than $100 \%$.
}

Table 3. Adequacy of knowledge, attitude and practice regarding Pap smear test

\begin{tabular}{lcc}
\hline Characteristics & \multicolumn{2}{l}{ Women } \\
\cline { 3 - 3 } & $\mathrm{n}$ & $\%$ \\
\hline Knowledge & & \\
$\quad$ Adequate & 147 & 52.3 \\
$\quad$ Inadequate & 134 & 47.7 \\
Attitude & & \\
$\quad$ Adequate & 86 & 30.6 \\
$\quad$ Inadequate & 195 & 69.4 \\
Practice & & \\
$\quad$ Adequate & 67 & 23.8 \\
$\quad$ Inadequate & 214 & 76.2 \\
\hline
\end{tabular}

ic characteristics of the women are shown in table 4. Significantly higher proportions of adequate knowledge were identified among women with above-secondary school $(\mathrm{p}<0.001)$, working $(\mathrm{p}=0.020)$, high monthly income $(\mathrm{p}=0.044)$, married $(\mathrm{p}=0.010)$, married once $(\mathrm{p}=$ $0.043)$, married at the age of $>25$ years $(\mathrm{p}=0.046)$ and those who use contraceptives $(\mathrm{p}=0.027)$. Adequate attitude towards the test was significantly higher in women with above-secondary school education $(\mathrm{p}<0.001)$, and working $(\mathrm{p}=0.005)$. Adequate practice was significantly associated with age of the women $(p=0.022)$, age at first marriage $(\mathrm{p}=0.031)$, and the number of years since the last visit to a gynaecologist ( $\mathrm{p}=0.016)$. Women aged 30 49 years, who married after 25 years of age, and visited the gynaecologist at least once in the last 2 years had a higher proportion of adequate practice.

In the multivariate logistic regression analysis, women's age, educational level, and visit to gynaecologists were significant factors associated with inadequate Pap smear practice (table 5). The odds ratio for inadequate Pap smear practice at the age of 20-29 years was 7.76 (95\% $\mathrm{CI}=2.49-24.20)$ compared to women at the age of 30-49 years. Women with educational level secondary school and below had an odds ratio of $2.85(95 \% \mathrm{CI}=1.12-7.23)$ for inadequate practice compared with women with educational level above secondary school. Women who visited a gynaecologist 2 years before the study had an odds ratio of 3.69 ( $95 \% \mathrm{CI}=1.49-9.10)$ for inadequate practice compared to those who visited in the past year. The educational level was the only factor significantly associated with inadequate knowledge and attitudes about Pap smear test, women with educational level secondary school and below had odds ratios of 2.95 (95\% CI $=1.37$ - 
Table 4. Association of the adequacy of knowledge, attitude and practice regarding Pap smear test with sociodemographic characteristics

\begin{tabular}{|c|c|c|c|c|c|c|c|}
\hline \multirow[t]{2}{*}{ Characteristic } & \multirow[t]{2}{*}{ Total } & \multicolumn{2}{|c|}{ Adequate knowledge } & \multicolumn{2}{|c|}{ Adequate attitude } & \multicolumn{2}{|c|}{ Adequate practice } \\
\hline & & n $(\%)$ & $\mathrm{p}$ value & $\mathrm{n}(\%)$ & $\mathrm{p}$ value & n (\%) & $\mathrm{p}$ value \\
\hline Age, years & & & 0.175 & & 0.618 & & 0.022 \\
\hline $20-29$ & 73 & $38(52.1)$ & & $24(32.9)$ & & $9(12.3)$ & \\
\hline $30-49$ & 178 & $98(55.1)$ & & $56(31.5)$ & & $51(28.7)$ & \\
\hline$\geq 50$ & 30 & $11(36.7)$ & & $7(23.3)$ & & $7(23.3)$ & \\
\hline Education level & & & $<0.001$ & & $<0.001$ & & 0.132 \\
\hline Secondary and below & 101 & $36(35.6)$ & & $15(14.9)$ & & $19(18.8)$ & \\
\hline Above secondary & 179 & $110(61.5)$ & & $72(40.2)$ & & $48(26.8)$ & \\
\hline Working status & & & 0.020 & & 0.005 & & 0.701 \\
\hline Housewife/retired & 102 & $44(43.1)$ & & $21(20.6)$ & & $23(22.5)$ & \\
\hline Working & 179 & $103(57.5)$ & & $66(36.9)$ & & $44(24.6)$ & \\
\hline Monthly income & & & 0.044 & & 0.073 & & 0.518 \\
\hline$<1,000 \mathrm{KD}$ & 135 & $62(45.9)$ & & $35(25.9)$ & & $30(22.2)$ & \\
\hline$\geq 1,000 \mathrm{KD}$ & 145 & $84(57.9)$ & & $52(35.9)$ & & $37(25.5)$ & \\
\hline Marital status & & & 0.010 & & 0.169 & & 0.701 \\
\hline Married & 251 & $138(55.0)$ & & $81(32.3)$ & & $59(23.5)$ & \\
\hline Divorced/widowed & 30 & $9(30.0)$ & & $6(20.0)$ & & $8(26.7)$ & \\
\hline Number of marriages & & & 0.043 & & 0.174 & & 0.891 \\
\hline Once & 258 & $140(54.3)$ & & $83(32.2)$ & & $62(24.0)$ & \\
\hline More than once & 22 & $7(31.8)$ & & $4(18.2)$ & & $5(22.7)$ & \\
\hline Age at first marriage, years & & & 0.046 & & 0.071 & & 0.031 \\
\hline$<20$ & 108 & $48(44.4)$ & & $26(24.1)$ & & $24(22.2)$ & \\
\hline $20-25$ & 124 & $73(58.9)$ & & $43(34.7)$ & & $26(21.0)$ & \\
\hline$>25$ & 30 & $19(63.3)$ & & $13(43.3)$ & & $13(43.3)$ & \\
\hline Number of pregnancies & & & 0.583 & & 0.869 & & 0.819 \\
\hline 0 & 21 & $11(52.4)$ & & $7(33.3)$ & & $6(28.6)$ & \\
\hline $1-5$ & 152 & $82(53.9)$ & & $44(28.9)$ & & $34(22.4)$ & \\
\hline$\geq 6$ & 73 & $34(46.6)$ & & $20(27.4)$ & & $17(23.3)$ & \\
\hline Contraceptives used & & & 0.027 & & 0.128 & & 0.362 \\
\hline No & 77 & $32(41.6)$ & & $18(24.0)$ & & $15(20.0)$ & \\
\hline Yes & 204 & $115(56.4)$ & & $69(33.5)$ & & $52(25.2)$ & \\
\hline Years since last visited gyne & cologist & & 0.416 & & 0.193 & & 0.016 \\
\hline$<1$ & 142 & $75(52.8)$ & & $46(32.4)$ & & $39(27.5)$ & \\
\hline $1-<2$ & 47 & $28(59.6)$ & & $17(36.2)$ & & $17(36.2)$ & \\
\hline$\geq 2$ & 72 & $34(47.2)$ & & $16(22.2)$ & & $10(13.9)$ & \\
\hline
\end{tabular}

$6.37)$ and $6.16(95 \% \mathrm{CI}=2.20-17.28)$, respectively, for inadequate knowledge and attitudes compared with women educated above secondary level.

\section{Discussion}

Despite its effectiveness as a method of controlling cervical cancer, the use of Pap smear testing remains incomplete and its promotion in the primary care setting provides an important opportunity for intervention [20]. Pap smear test for the early detection of cervical cancer is not, by itself, sufficient for reducing the mortality. The positive effect of the test depends on its being properly utilized by the target population. The practice of taking the test depends on a range of factors that include the healthcare system and its professionals and the women themselves. In the present study, we have focused on knowledge, attitudes and practice of cervical cancer screening from the perspective of women only. 
Table 5. Significant factors associated with inadequate knowledge, attitudes or practice of Pap smear test among studied women as estimated by the multiple logistic regression analysis ${ }^{1}$

\begin{tabular}{|c|c|c|c|}
\hline Factor & $\begin{array}{l}\text { Odds ratio } \\
\text { (adjusted) }\end{array}$ & $95 \% \mathrm{CI}^{2}$ & $\begin{array}{l}\mathrm{p} \\
\text { value }\end{array}$ \\
\hline \multicolumn{4}{|l|}{ Inadequate knowledge } \\
\hline \multicolumn{4}{|l|}{ Education level } \\
\hline Above secondary (reference group) & 1.00 & & \\
\hline Secondary and below & 2.95 & $1.37-6.37$ & 0.006 \\
\hline \multicolumn{4}{|l|}{ Inadequate attitudes } \\
\hline \multicolumn{4}{|l|}{ Education level } \\
\hline Above secondary (reference group) & 1.00 & & \\
\hline Secondary and below & 6.16 & $2.20-17.28$ & 0.001 \\
\hline \multicolumn{4}{|l|}{ Inadequate practice } \\
\hline \multicolumn{4}{|l|}{ Age, years } \\
\hline $30-49$ (reference group) & 1.00 & & \\
\hline $20-29$ & 7.76 & $2.49-24.20$ & $<0.001$ \\
\hline$\geq 50$ & 0.66 & $0.21-2.07$ & 0.473 \\
\hline \multicolumn{4}{|l|}{ Education level } \\
\hline Above secondary (reference group) & 1.00 & & \\
\hline Secondary and below & 2.85 & $1.12-7.23$ & 0.028 \\
\hline \multicolumn{4}{|c|}{ Number of years since last visited gynecologist } \\
\hline$<1$ (reference group) & 1.00 & & \\
\hline $1-<2$ & 0.79 & $0.34-1.85$ & 0.589 \\
\hline$\geq 2$ & 3.69 & $1.49-9.10$ & 0.005 \\
\hline \multicolumn{4}{|c|}{$\begin{array}{l}{ }^{1} \text { The variables age, education level, working status, income, marital } \\
\text { status, number of marriages, age at first marriage, number of pregnancies, } \\
\text { use of contraceptives, and number of years since last visited gynaecologist } \\
\text { were included in the model as independent variables. } \\
\quad 295 \% \text { CI = 95\% confidence interval for adjusted odds ratio. }\end{array}$} \\
\hline
\end{tabular}

Our finding that $76.9 \%$ of the women had ever heard about the cervical cancer screening test is similar to those reported for Singapore [21], Vietnamese-American women [22], and South Asian women living in the New York City area [23], but lower when compared with those reported for developed countries $[24,25]$ and some developing countries such as Argentina [19] and Brazil [26]. The differences in the above studies could be due to different populations involved and different levels of intervention such as existing population-based screening programmes, or mass media campaigns to popularize cervical screening. Even though a moderate proportion of our sample had heard about the test, only $52 \%$ had adequate knowledge similar to reports from South Africa and Kenya $[27,28]$, possibly due to lack of a national cervical screening programme. The test, therefore was usually done in circumstances such as non-specific gynaecological complaints, during pregnancy, or as part of postnatal care, where the doctor usually asks for the test as part of the general check-up.
The screening rate of $23.8 \%$ of this study is similar to that of other developing countries [14, 15, 27, 28], but less than that of developed counties $[9,29,30]$. The fact that about half of the respondents in our study did not have adequate knowledge of cervical cancer screening could be responsible in part for not having the test among these women.

Our study identified the level of education as the only significant factor independently associated with inadequate knowledge and attitude about Pap smear test when adjusted for the effect of other factors in multivariate logistic regression analysis. Similar findings have been reported in several studies [31-35]. Some of these studies [31, 33-35] also showed that age was associated with knowledge and attitude about Pap smear test. This increase of knowledge of Pap smears with age and education may indicate that women with better general education have better communication skills and a better ability to absorb information. Equally important, age, level of education, and number of years since the last visit to a gynaecologist were significant factors independently associated with inadequate Pap smear practice and were consistent with many other studies conducted in different parts of the world [22, 31-35].

Our results can be explained by the fact that younger women tend to be healthier and thus would not seek medical advice or would have relatively less contact with the health service providers. Furthermore, physicians and patients usually behave differently in response to illness level according to the patient's age, which makes it less likely to ask for the test in younger age group women unless symptomatic. The fact that many young women in the 20-29 years age group had not taken the test may be due to the low background risk for cervical cancer in the country. The WHO recommendation to start screening on women aged 25 or even 30 years should be taken into consideration while planning an appropriate national screening programme in the near future in Kuwait.

The main reason given for not having had a Pap smear was that it was not suggested by the doctor (48.4\%), which was similar to the studies from South Africa [27], among Vietnamese American women [22] and Argentina [19]. This finding may indicate that many women either do not feel they have the right, or do not possess enough knowledge to request the test during appointments with doctors. Other important reasons which included embarrassment, fear of infection, fear of discovery of cancer and no symptoms, misconception about the test being painful have also been reported in other studies in different proportions $[14,15,19]$. 
Barriers to cervical cancer screening have been shown to exist in many countries. The greatest barrier to effective cervical screening is the inadequate knowledge about the test. Utilization of the Pap test for cervical cancer screening will not increase unless knowledge is improved and barriers are eliminated. The findings of our study suggest that it is important to provide information about the value of cervical smear test and to contradict barriers. Providing information through leaflets and giving clear explanation about the test procedure can help in reducing anticipated distress and embarrassment.

The finding that about $79 \%$ of the respondents would prefer a female doctor to conduct the test is expected among Muslim women as in other Gulf countries. Since it is well established that satisfaction is a predictor of compliance, it is important to examine ways of increasing women's satisfaction with the cervical cancer screening service provided.

\section{Conclusion}

A well-designed health education programme on cervical cancer and benefits of screening would increase the awareness among women. On that issue, a multimedia approach utilizing pictorials, audio-visual and personal communication on cervical cancer could yield beneficial results. One more important point is the fact that better communication with health professionals and improvement of access to health care services should increase the rate of cervical cancer screening.

\section{Acknowledgements}

We thank Prof. Mohamed A.A. Moussa and his assistant Mr. Joseph E. Gomez from the Department of Community Medicine, Faculty of Medicine, Kuwait University, for their advice and help in statistical analyses.

\section{References}

1 Parkin DM, Bray FI, Devesa SS: Cancer burden in the year 2000: the global picture. Eur J Cancer 2001;37(suppl 8):S4-S66.

2 World Health Organization: Cervical Cancer Screening in Developing Countries. Report of a WHO Consultation. Geneva, WHO Press, 2002.

-3 Parkin DM, Bray F, Ferlay J, Pisani P: Global cancer statistics, 2002. CA Cancer J Clin 2005;55:74-108.

4 Brink AATP, Zielinski GD, Steenbergen RDM, Snijders PJF, Meijer CJLM: Clinical relevance of human papillomavirus testing in cytopathology. Cytopathology 2005;16: $7-12$.

5 Gustafsson L, Ponten J, Zack M, Adami HO: International incidence rates of invasive cervical cancer after introduction of cytological screening. Cancer Causes Control 1997;8: 755-763.

-6 Janerich DT, Hadjimichael O, Schwartz PE, Hadjimichael O, Schwartz PE, Lowell DM, Meigs JW, Merino MJ, Flannery JT, Polednak AP: The screening histories of women with invasive cervical cancer, Connecticut. Am J Public Health 1995;85:791-794.

7 Hristova L, Hakama M: Effect of screening for cancer in the Nordic countries on deaths, cost and quality of life up to the year 2017. Acta Oncol 1997;36(suppl 9):1-60.

8 Crum CP, Abbott DW, Quade BJ: Cervical cancer screening: from the Papanicolaou smear to the vaccine era. J Clin Oncol 2003; 21(suppl 10):224-230.
-9 Saslow D, Runowicz CD, Solomon D, Moscicki AB, Smith RA, Eyre HJ, Cohen C; American Cancer Society: American Cancer Society Guideline for the early detection of cervical neoplasia and cancer. CA Cancer J Clin 2002;52:342-362.

10 ACOG Committee on Practice Bulletins: ACOG Practice Bulletin: clinical management guidelines for obstetrician-gynecologists. Number 45. August 2003. Cervical cytology screening (replaces committee opinion 152, March 1995). Obstet Gynecol 2003; 102:417-427.

11 World Health Organization: Comprehensive Cervical Cancer Control: A Guide to Essential Practice. Screening for Cervical Cancer. Geneva, WHO Press, 2002, p 86.

12 Jamal AA, Al-Maghrabi JA: Profile of Pap smear cytology in the Western region of Saudi Arabia. Saudi Med J 2003;24:12251229.

13 Wasti S, Ahmed W, Jafri A, Khan B, Sohail R, Hassan S: Analysis of cervical smears in a Muslim population. Ann Saudi Med 2004; 24:189-192.

14 Bener A, Denic S, Alwash R: Screening for cervical cancer among Arab women (brief communication). Int J Gynecol Obstet 2001; 74:305-307.

15 Maaita M, Brakat M: Jordanian women's attitudes towards cervical cancer screening and cervical cancer. J Obstet Gynecol 2002; 22:421-422.

16 Kuwait Cancer Registry: Annual Report 2002: Kuwait. Ministry of Health, State of Kuwait, 2003.
17 World Health Organization: WHO Statistical Information System (WHOSIS): Mortality and Burden of Disease. http://www.who. int/whosis/en/index.html.

18 Kapila K, George SS, Al-Shaheen A, Al-Ottibi MS, Pathan SK, Sheikh ZA, Haji BE, Mallik MK, Das DK, Francis IM: Changing spectrum of squamous cell abnormalities observed on Papanicolaou smears in $\mathrm{Mu}$ barak Al-Kabeer Hospital, Kuwait, over a 13 year period. Med Princ Pract 2006;15:253259.

19 Gamarra CJ, Paz EPA, Griep RH: Knowledge, attitudes, and practice related to $\mathrm{Pa}$ panicolaou smear test among Argentina's women. Saude Publica 2005;39:270-276.

20 Bailie R, Petrie K: Women's attitudes to cervical smear testing. NZ Med J 1990;103:293295.

-21 Seow A, Wong ML, Smith WC, Lee HP: Beliefs and attitudes as determinants of cervical cancer screening: a community-based study in Singapore. Prev Med 1995;24:134141.

22 Nguyen TT, McPhee SJ, Nguyen T, Lam T, Mock J: Predictors of cervical Pap smear screening awareness, intention, and receipt among Vietnamese-American women. Am J Prev Med 2002;23:207-214.

23 Islam N, Kwon SC, Senie R, Kathuria N: Breast and cervical cancer screening among South Asian women in New York City. J Immigr Minor Health 2006;8:211-221.

$24 \mathrm{Yu}$ CK, Rymer J: Women's attitudes to and awareness of smear testing and cervical cancer. Br J Fam Plann 1998;23:127-133. 
25 Hasenyager C: Knowledge of cervical cancer screening among women attending a university health center. J Am Coll Health 1999;47: 221-224.

-26 Moreira ED Jr, Oliveira BG, Ferraz FM, Costa S, Costa Filho JO, Karic G: Knowledge and attitudes about human papillomavirus, Pap smears, and cervical cancer among young women in Brazil: implications for health education and prevention. Int J Gynecol Cancer 2006;16:599-603.

27 Wellensiek N, Moodley M, Moodley J, Nkwanyana N: Knowledge of cervical cancer screening and use of cervical screening facilities among women from various socioeconomic backgrounds in Durban, Kwazulu Natal, South Africa. Int J Gynecol Cancer 2002;12:376-382.
28 Gichangi P, Estambale B, Bwayo J, et al: Knowledge and practice about cervical cancer and Pap smear testing among patients at Kenyatta National Hospital, Nairobi, Kenya. Int J Gynecol Cancer 2003;13:827833.

29 Chavez LR, Hubbell FA, Mishra SI, Valdez RB: The influence of fatalism on self-reported use of Papanicolaou smears. Am J Prev Med 1997;13:418-424.

30 Anttila A, Ronco G, Clifford G, Bray F, Hakama M, Arbyn M, Weiderpass E: Cervical cancer screening programmes and policies in 18 European countries. Br J Cancer 2004;91:935-941.

31 Siahpush M, Singh GK: Sociodemographic predictors of Pap test receipt, currency and knowledge among Australian women. Prev Med 2002;35:362-368.
32 Sabates R, Feinstein L: The role of education in the uptake of preventative health care: the case of cervical screening in Britain. Soc Sci Med 2006;62:2998-3010.

33 Liao CC, Wang HY, Lin RS, Hsieh CY, Sung FC: Addressing Taiwan's high incidence of cervical cancer: factors associated with the nation's low compliance with Papanicolaou. Public Health 2006;120:1170-1176.

-34 Qi V, Pillips SP, Hopman WM: Determinants of a healthy lifestyle and use of preventive screening in Canada. BMC Public Health 2006;6:275

35 Maxwell CJ, Bancej CM, Snider J, Vik SA: Factors important in promoting cervical cancer screening among Canadian women: findings from the 1996-97 National Population Health Survey (NPHS). Can J Public Health 2001;92:127-133. 